\title{
An analysis of the Effects of Value-added Tax Reform with Using the DID Method
}

\author{
Meiping liu, a , \\ 1 The CPC Party school of Xiamen Municipal Committee, \\ Xiamen, 361000, China \\ 2 Xiamen Office of State Administration of Taxation, \\ Xiamen, 361000, China \\ a meipingliu@163.com, ${ }^{\mathrm{b}}$ 361262636@qq.com
}

\begin{abstract}
Keywords: Value-added tax reform; Difference-in-Difference; Firm performance
Abstract. This paper employs survey data from China National Taxation Bureau for 2006-2012 and applies the method ofDifference-in-Difference to study the effects of value-added tax reform, which was put into effect nationwide in 2009. The empirical findings show that when the VAT system changed from production-based to consumption-based, a typical firm's VAT burden has fallen significantly during the three year period after the nationwide reform. In addition, we have obtained supportingevidence that the VAT reform encourages firm investment and improves firm performance. These results suggest that the valueadded tax reform in 2009 has obtained the good policy effects, which are in line with the original intentions of the reform.
\end{abstract}

\section{Introduction}

Our country started from 1994 in the true sense of value added tax policy, In January 2009, the full implementation of consumer VAT oriented value-added tax system, marks the start of a new round of tax reform in our country. it has very important theory value and practical significance, from a long time window to study the effect of VAT to enterprise development in our country, and comprehensive evaluation of the effect of the policy of reform. This paper will help us to understand our tax reform effect in the new era economic environment and further enrich the research on tax policy effect.which based on the latest implementation of value-added tax system reform for the event, through the recent period of nationwide sample data empirically, and tax burden level, from the enterprise investment behavior and investment benefits the effect of the policy of VAT from different angles.

\section{With the household enterprise VAT tax basic situation}

The tax investigation is based on region economy, enterprise scale, industry characteristics, the tax situation we should carry out the sampling method, ensure the distribution of the sample are in conformity with the overall situation, has good representativeness. And, the survey is made by national ministry of finance, state administration of taxation shall be responsible for implementation, supervise and bottom-up through from top to bottom layers of layers of summary report to finish, better ensure the quality of the data acquisition. Because this article studies the effect of VAT reform, the sample is only in view of the industry impose value added tax, so we have to cut out the companies do not belong to the VAT reform. According to caishui [2004] 156 date file, only for a specific industry, the company can according to the consumer VAT tax tax.

In this paper, according to national standand in classification of economic sectors (GB/T4754-2002) classification criteria, select the following industry enterprises as the research sample: 1 . The farming, forestry, animal husbandry and fishery; 2 . The mining industry; 3 . Manufacturing; 4 . Electricity, heat, gas and water production and supply industry; 5 . Wholesale and retail. 
To ensure comparability for the data, we adopted the same door samples (as long as the enterprises in the research of time window with missing data, that is the sample of this enterprise from). According to tax survey database, we finally confirmed in the period 2006-2006 with a sample of 238258 households.

With the household enterprise VAT tax are shown in table 1. You can see from table 1, in 2009 before the comprehensive transformation of VAT, the VAT tax at 4. $26 \%$ fluctuate, After tax reform, tax suddenly from $4.27 \%$ to $4.13 \%$, and the downward trend to continue in the coming years,

Reduction in 2010 to below $4 \%$ for the 3. 99\%, 2011 years to 3. 82\%, a slight rebound in 2012 to 3. $91 \%$. Therefore, the tax reform in the past few years has made obvious effect of tax cuts.

\section{Questions and research design}

\section{questions}

In this paper, using the data from the national tax survey using double Difference DID (Difference - in - Difference) inspection method, to our 2009 full VAT transformation as the breakthrough point, the focus of the research question, in turn, are:

(1)It in the short term has the obvious decline in tax, Then, with the passage of time, the tax burden in a quite long period of downward trend will continue?

(2) Because of enterprise fixed assets input deductible, equivalent to increase the cash flow of the current management of the enterprise. Therefore, this paper studies the second problem is that, after the tax reform of enterprise fixed assets investment demand significantly increased?

(3) The studies have shown that listed companies tend to excessive investment, And this kind of behavior will weaken the enterprise management benefit, and ultimately damage the whole social resource allocation efficiency.

So, the tax reform driven enterprise capital expansion will induce excessive investment behavior, so as to reduce the enterprise management benefit? This is the test of this paper focus on the third question.

\section{Study design}

1. The selection of the sample

Based on as the main research during 2006-2006, with registered in pilot areas (i.e., jilin, liaoning, heilongjiang provinces in the northeast and central parts of shanxi, anhui, jiangxi, henan, hubei, hunan, six provinces) of the same family enterprise to control sample, In transition area of the enterprise as the research sample, using double difference (DID) analysis method, research on the enterprise value-added tax, value-added tax reform and the influence of the enterprise management benefit of investment in fixed assets. To ensure the robustness of the results, this paper eliminated enterprise annual data has the following characteristics and no including that

(1) Do not belong to the VAT tax sector by enterprises. (2) To any inside the sample during years of owners' equity is negative or zero, or a lack of relevant financial indicators of enterprises.

\section{Building a Double difference model}

On July 1, 2004, our country in the three provinces in northeast China VAT reform pilot, take the lead in equipment manufacturing, oil, chemical industry and so on six big transition from production VAT to consumer gradually. 
After a series of pilot scale promotion, on January 1, 2009 officially in the nationwide implementation of the VAT reform, this event is equivalent to a "natural experiment" (natural experiment). we should not only will the northeast parts of the central region, and the rest of the country's enterprises, and to all the businesses before 2009 and after 2009, all enterprises, comprehensive account of the differences of these two methods, is the double Difference of econometric model (Difference - in - Difference model). Traditional ordinary least squares method takes a policy variables as explained variable regression analysis, but this simple method is easy to suffer endogeneity problem, affect the reliability of the regression results. The double difference method by controlling the interaction effect between the dependent variable and independent variable can better solve the above problem. Also because of these advantages, the method is gradually accepted by many scholars in recent years, has been widely applied to the study of policy effect. For example, Card and Krueger (1994) using the double difference method is used to analysis the fast food industry data, New Jersey and Pennsylvania found that minimum wage increase did not reduce employment; Zhou Li Ann and ye Chen (2005) using the double difference method is used to study China's rural reform of taxes and fees to the influence of farmers' income growth rate; Zheng Xinye etc. (2011) based on the double difference method to study reform of the "county" was made on the influence of the economic growth.

(1) The dependent variable and explanatory variables

From this article, the research object, the concrete method of double difference model is set, in 2009 the VAT in the value-added tax policy does not change the pilot areas of corresponding industry enterprises as the control sample, in order to implement VAT area (or areas other than the pilot areas, hereinafter referred to as the transition region) of the enterprise as a treatment group of samples, through the control of other factors, comparing the difference between the policy post-processing group and the control group, inspection policy effect thereby. We use the VAT tax, proportion of investment in fixed assets, return on total assets, respectively is as explained variable; With variable "policy" reflect whether samples for processing. Among them, the value of 1 represents companies implement VAT regions in 2009, the value of 0 represents 2009 years after the implementation of the new VAT policy does not change the pilot areas of the company. With variable "period" reflects the process of reform and implementation of value-added tax policy in 2009 that year and since then the values 1 , otherwise 0 . To test reform effect, we set up by item (DID), it is the policy and the period of the item.

When the policy and period to 1 at the same time, pay by item value is 1 , otherwise 0 . Through this form, we will sample is divided into four groups: before the reform of the treatment group (policy $=1$, period $=0$ ), treatment group after the reform, the policy $=1$, period $=1)$, before the reform of the control group (policy $=0$, period $=0$ ) and the control group after the reform, the policy $=0$, period $=$ 1). The double difference model is:

\section{Yi, $t=\alpha 0+\alpha 1$ Policyi, $t+\alpha 2$ Periodi, $t+\alpha 3 D I D i, t+\varepsilon i, t(1)$}

Y to be explained variable, respectively the VAT tax payable VAT (enterprise) proportion of main business income of the same period, the proportion of investment in fixed assets (enterprise original value of fixed assets accounted for the proportion of total assets at the same period) and return on total assets (net income to total assets over the same ratio, namely the ROA); Alpha 1 to control the difference between the treatment group and control group, alpha 2 control time of treatment group and control group with common shocks, alpha 3 is variable, we really care about is can reflect the reform effect coefficient, I on behalf of the enterprise, $t$ on behalf of the time. Details are as follows: for the control group, that is, the policy $=0$, by type (1), the control group before and after the reform to be remember Y:

$$
Y_{i, t}=\left\{\begin{array}{l}
\alpha_{0} \\
\alpha_{0+} \alpha_{2}
\end{array}\right.
$$


When the Period $=0$, that is, before the reform. When the Period $=1$, after the reform

Therefore, during the period before and after the reform, the control group changes for alpha 2 Y. Alpha 2 reflects the macro economy, technical innovation and the influence of factors on the Y; For the treatment group, namely the policy $=1$, by type $(1)$, treatment group before and after the reform to be remember Y:

$$
Y_{i, t}=\left\{\begin{array}{l}
\alpha_{0+} \alpha_{1} \\
\alpha_{0+} \alpha_{1+} \alpha_{2+} \alpha_{3}
\end{array}\right.
$$

SO, during the period before and after the reform, changes in the treatment group Y for alpha alpha 2 +3 . Therefore, the "net effect" of value-added tax reform policy in 2009 for alpha alpha 3 - alpha $2+$ $2=$ alpha 3 . If the VAT reform has negative effect to the enterprise value-added tax, so alpha 3 symbols should be significantly negative; If the VAT reform helps enterprises to increase investment, so alpha 3 symbols should be significantly positive; If the VAT reform can improve enterprise efficiency, then alpha 3 symbols should be significantly positive. After this treatment, the general factors influencing the national enterprises such as macro economy, the influence of the technological innovation of Y will be removed, so that they can more accurately estimate the effect of the policy of VAT reform.

\section{(2) Control variables}

In order to guarantee the robustness, we add the following variables in the model to control the enterprise characteristics of potential impact on the dependent variable: (1) firm Size (Size), USES the enterprise total assets at the beginning of the natural logarithm of measure; (2) the financial leverage (Lev), USES the enterprise total liabilities and total assets at the beginning of the beginning of the ratio of the measured; (3) Growth (Growth), the total assets of the enterprise at the end of the beginning of relative to the Growth rate of total assets to measure; (4) Age (Age), the use of the fiscal year to year enterprise set up year intervals to measure; (5) the enterprise nature of dummy variable, we will enterprise according to the nature of the ownership is divided into state-owned enterprises, private enterprises and foreign enterprises, and introduces two dummy variables Control; Dummy variable (6) industry, the research enterprise involved in agriculture, mining, manufacturing, electricity, heat, gas and water production and supply industry, wholesale and retail, we introduce four dummy variable to control; (7) years dummy variable, we studied the time window is 2006 -2012. In 2012, a total of seven years, we have introduced six years dummy variable control. Thus, in this paper, the general regression model building is set as follows:

\section{Yi, $t=\alpha 0+\alpha 1$ Policyi, $t+\alpha 2$ Periodi, $t+\alpha 3$ DIDi, $t+\alpha 4$ Sizei, $t+\alpha 5$ Levi, $t+\alpha 6$ Growthi, $\mathrm{t}+\alpha 7$ Agei, $\mathrm{t}+\mathbf{\varepsilon i}, \quad \mathrm{t}(2)$}

\section{The empirical results and analysis Descriptive statistics}

Table3 lists all sample enterprises related variables of descriptive statistics. As the main explanatory variables, the value-added Tax (Tax) a maximum of $16.4 \%$, the minimum value is 0 , the mean of $4.1 \%$, the standard deviation of 3.5\%, show that there is biggish difference between household enterprise VAT Tax; Proportion of investment in fixed assets (Inv) averages $49.8 \%$, the median $42.5 \%$, the standard deviation is $34.8 \%$, show that sample period, the enterprise investment decision-making; there are some differences between Total return on assets (ROA) of the mean and the median respectively 0.037 and 0.020 , minimum value is 0.240 , the maximum is reached 0.414 , shows that different enterprises there are evident differences on the business performance. 
Table 1 Variable descriptive statistics

\begin{tabular}{l|l|l|l|l|l}
\hline & ave & mid & mini & maxi & St. devi \\
\hline VAT Tax & 0.041 & 0.034 & 0 & 0.164 & 0.035 \\
\hline INV & 0.498 & 0.425 & 0.01 & 1.728 & 0.348 \\
\hline ROA & 0.037 & 0.02 & -0.24 & 0.414 & 0.093 \\
\hline Size & 11.596 & 11.443 & 8.983 & 15.695 & 1.453 \\
\hline Lev & 0.6 & 0.611 & 0.022 & 1.377 & 0.271 \\
\hline Growth & 0.167 & 0.092 & -0.426 & 1.793 & 0.337 \\
\hline Age & 11.11 & 10 & 1 & 35 & 6.229 \\
\hline
\end{tabular}

\section{Regression analysis}

Table 4 lists the empirical regression results of double difference model. Among them, the Base Line in the Control sample and the regression coefficient of Treated respectively reflect the Control group and treatment group in 2009 before the implementation of value-added tax policy reform of VAT tax, the proportion of investment in fixed assets and the average return on assets, the Diff (BL) for the difference. Can be seen from the results, the Diff (BL) of regression coefficients were not significant, before the implementation of value-added tax policy reform, the control group and treatment group there is no significant difference in the above three aspects. Follow Up sample of the regression coefficient of the Control and Treated respectively reflect the Control group and treatment group policy of value added tax reform in 2009 after the implementation of value-added tax, the proportion of investment in fixed assets and the average return on assets, the Diff (FU) for the difference. Can be seen from the results, the Diff (FU) regression coefficients were not significant, in value-added tax policy reform after implementation, the control group and treatment group on the performance of the growing convergence in the above three aspects.

DID is the most concerned in this paper, the key variables, it accurately capture the actual effect of policy implementation. Seen from the perspective of value-added tax, DID the regression coefficient is negative, for - 0. 002, and reached $1 \%$ significance level, in 2009 since the implementation of value-added tax policy reform implement VAT region enterprise VAT tax from a long time, there has been a significant decline in change trend; Look from the Angle of investment in fixed assets ratio, DID the regression coefficient is positive, as 0.013 , reached $1 \%$ significance level, since the implementation of value-added tax policy reform in 2009 enterprises implement VAT region has a more obvious increase of fixed asset investment, enterprise investment activity was significantly enhanced; Seen from the perspective of return on assets, DID the regression coefficient is positive, as 0.003 , reached 5\% significance level, value added tax policy reform in 2009, the economic benefits of enterprises implement VAT area has increased significantly, illustrate the VAT reform brings the increase of business investment spending does not damage efficiency of enterprise management, but to a certain extent, improve the operating performance of the enterprise.

\section{Robust testing}

VAT policy in 2004, the first pilot, three provinces in northeast China in 2007 to promote to the six provinces in central. Because this data is from the beginning in 2006, means that the central six provinces in 2006-2009 years between the VAT policy has changed, affected the DID in the setting of 
the control group. To this, we will study the window is set in 2007-2007. Results show that the window the findings in the new study, still shows the conclusion of this article has good robustness.

It should be pointed out that, due to the policy of value added tax is first by local area gradually spread across the country, in 2009 the implementation of reform in enterprises is likely to be a policy that will soon spread to the region have certain expectations, thus some measures may be taken, such as reduce the fixed capital investment before the reform, in order to obtain preferential tax under the new VAT system. In other words, this article found that the effect of the policy of likely affected by the enterprise for policy expectations. However, if the VAT investment increase is due to the expected tax reform and delay the investment behavior of the inflated phenomenon, then we should observe the increased investment in enterprise phenomenon will be weakened with time delay. But the empirical results of this paper is, enterprise's investment to maintain or even increase in a relatively long period of time has a tendency to a certain extent improve (see table 6 and table 7 DID coefficient comparison). So enterprises expectations may explain part of the investment increase, but it can't fully explain the increase of investment, so this paper observed the VAT reform effect is more credible.

Table 2

Regression analysis of tax burden after the tax reform, tthe investment and benefit (2006-2012)

\begin{tabular}{|c|c|c|c|c|}
\hline & & The VAT tax & $\begin{array}{l}\text { Proportion of } \\
\text { investment in } \\
\text { fixed assets }\end{array}$ & $\begin{array}{l}\text { Return } \\
\text { on assets }\end{array}$ \\
\hline \multirow[t]{3}{*}{ Base Line } & Control & $\begin{array}{l}0.023 \text { *** } \\
(6.85) \\
\end{array}$ & $\begin{array}{l}0.490 \text { *** } \\
(13.88) \\
\end{array}$ & $\begin{array}{l}0.025^{* * *} \\
(3.53)\end{array}$ \\
\hline & Treated & $\begin{array}{l}0.026^{* * * *} \\
(8.62)\end{array}$ & $\begin{array}{l}0.483^{* * * *} \\
(13.96)\end{array}$ & $\begin{array}{l}0.022^{* * * *} \\
(2.88)\end{array}$ \\
\hline & $\operatorname{Diff}(\mathrm{BL})$ & $\begin{array}{l}0.003 \\
(1.06)\end{array}$ & $\begin{array}{l}-0.008 \\
(-0.26)\end{array}$ & $\begin{array}{l}-0.003 \\
(-0.54)\end{array}$ \\
\hline \multirow[t]{4}{*}{$\begin{array}{l}\text { Follow } \\
\text { Up }\end{array}$} & Control & $\begin{array}{l}0.020^{* * *} \\
(6.16)\end{array}$ & $\begin{array}{l}0.490^{* * * *} \\
(14.37)\end{array}$ & $\begin{array}{l}0.025^{* * * *} \\
(3.58)\end{array}$ \\
\hline & Treated & $\begin{array}{l}0.021 \text { *** } \\
(5.54)\end{array}$ & \begin{tabular}{|l|}
$0.495^{* * * *}$ \\
$(15.02)$ \\
\end{tabular} & $\begin{array}{l}0.025^{* * *} \\
(4.19)\end{array}$ \\
\hline & $\operatorname{Diff}(\mathrm{FU})$ & $\begin{array}{l}0.001 \\
(0.83) \\
\end{array}$ & $\begin{array}{l}0.005 \\
(0.42) \\
\end{array}$ & $\begin{array}{l}-0.000 \\
(0.53)\end{array}$ \\
\hline & DID & $\begin{array}{l}-0.002^{* * *} \\
(-6.15)\end{array}$ & $\begin{array}{l}0.013^{* * * *} \\
(3.67)\end{array}$ & $\begin{array}{l}0.003^{* *} \\
(2.14)\end{array}$ \\
\hline \multirow[t]{10}{*}{$\begin{array}{l}\text { Control } \\
\text { Variables }\end{array}$} & Size & $\begin{array}{l}-0.001 * * * \\
(-9.58)\end{array}$ & $\begin{array}{l}-0.005^{* * *} \\
(-4.94)\end{array}$ & $\begin{array}{l}0.006 * * * \\
(23.06)\end{array}$ \\
\hline & Lev & $\begin{array}{l}-0.015^{\text {**** }} \\
(-27.79)\end{array}$ & $\begin{array}{l}-0.071 * * * \\
(-12.52)\end{array}$ & $\begin{array}{l}-0.091 \text { *** } \\
(-70.55)\end{array}$ \\
\hline & Growth & $\begin{array}{l}-0.004^{* * *} \\
(-17.75)\end{array}$ & $\begin{array}{l}-0.248 * * * \\
(-105.70) \\
\end{array}$ & $\begin{array}{l}0.034 * * * \\
(46.51) \\
\end{array}$ \\
\hline & Age & $\begin{array}{l}0.000^{* * * *} \\
(7.54) \\
\end{array}$ & $\begin{array}{l}0.004 * * * \\
(16.20) \\
\end{array}$ & $\begin{array}{l}-0.000^{* * *} \\
(-7.29)\end{array}$ \\
\hline & year & control & control & control \\
\hline & area & control & control & control \\
\hline & nature & control & control & control \\
\hline & industry & control & control & control \\
\hline & Obs & 238258 & 238258 & 238258 \\
\hline & Adj- R 2 & 0.20 & 0.26 & 0.12 \\
\hline
\end{tabular}

Note: the value in the parentheses is $\mathrm{t}$ statistic is significantly different from zero. *, ** and ***, respectively significance level of $10 \%, 5 \%$ and $5 \%$ (two-tailed test). 
Table3

Regression analysis of tax burden after the tax reform, tthe investment and benefit (2007-2012)

\begin{tabular}{|c|c|c|c|c|}
\hline & & The VAT tax & $\begin{array}{l}\text { Proportion of } \\
\text { investment in } \\
\text { fixed assets }\end{array}$ & $\begin{array}{l}\text { Return } \\
\text { on assets }\end{array}$ \\
\hline \multirow[t]{3}{*}{ Base Line } & Control & $\begin{array}{l}0.031 \text { *** } \\
(9.03)\end{array}$ & $\begin{array}{l}0.524 * * * \\
(15.31)\end{array}$ & $\begin{array}{l}0.018 * * * \\
(2.96)\end{array}$ \\
\hline & Treated & $\begin{array}{l}0.037 * * * \\
(13.24)\end{array}$ & $\begin{array}{l}0.511 * * * \\
(14.76)\end{array}$ & $\begin{array}{l}0.017 * * \\
(2.12)\end{array}$ \\
\hline & Diff( BL) & $\begin{array}{l}0.006^{*} \\
(1.92)\end{array}$ & $\begin{array}{l}-0.013 * * \\
(-2.37)\end{array}$ & $\begin{array}{l}-0.001 \\
(-0.12)\end{array}$ \\
\hline \multirow[t]{4}{*}{$\begin{array}{l}\text { Follow } \\
\text { Up }\end{array}$} & Control & $\begin{array}{l}0.024 * * * \\
(7.89)\end{array}$ & $\begin{array}{l}0.519 * * * \\
(15.12)\end{array}$ & $\begin{array}{l}0.020 * * * \\
(3.58)\end{array}$ \\
\hline & Treated & $\begin{array}{l}0.027 * * * \\
(8.65)\end{array}$ & $\begin{array}{l}0.520 * * * \\
(15.17)\end{array}$ & $\begin{array}{l}0.024 * * * \\
(4.03)\end{array}$ \\
\hline & Diff( FU) & $\begin{array}{l}0.003 \\
(1.54)\end{array}$ & $\begin{array}{l}0.001 \\
(0.42)\end{array}$ & $\begin{array}{l}0.004^{*} \\
(1.73)\end{array}$ \\
\hline & DID & $\begin{array}{l}-0.003 * * * \\
(-8.29)\end{array}$ & $\begin{array}{l}0.014 * * * \\
(4.01)\end{array}$ & $\begin{array}{l}0.005^{* * *} \\
(2.60)\end{array}$ \\
\hline \multirow[t]{10}{*}{$\begin{array}{l}\text { Control } \\
\text { Variables }\end{array}$} & Size & $\begin{array}{l}-0.001 * * * \\
(-11.23)\end{array}$ & $\begin{array}{l}-0.004 * * * \\
(-3.67)\end{array}$ & $\begin{array}{l}0.004 * * * \\
(16.22)\end{array}$ \\
\hline & Lev & $\begin{array}{l}-0.010 * * * \\
(-16.53)\end{array}$ & $\begin{array}{l}-0.083 * * * \\
(-14.87)\end{array}$ & $\begin{array}{l}-0.077 * * * \\
(-53.12)\end{array}$ \\
\hline & Growth & $\begin{array}{l}-0.005^{* * *} \\
(-18.23)\end{array}$ & $\begin{array}{l}-0.182 * * * \\
(-78.32)\end{array}$ & $\begin{array}{l}0.041^{* * * *} \\
(63.22)\end{array}$ \\
\hline & Age & $\begin{array}{l}0.001 * * * \\
(13.88)\end{array}$ & $\begin{array}{l}0.005^{* * * *} \\
(18.71) \\
\end{array}$ & $\begin{array}{l}0.000 * * \\
(2.10) \\
\end{array}$ \\
\hline & year & control & control & control \\
\hline & area & control & control & control \\
\hline & nature & control & control & control \\
\hline & industry & control & control & control \\
\hline & Obs & 204325 & 204325 & 204325 \\
\hline & Adj- R 2 & 0.23 & 0.29 & 0.11 \\
\hline
\end{tabular}

Note: the value in the parentheses is $\mathrm{t}$ statistic is significantly different from zero. $*, * *$ and $* * *$, respectively significance level of $10 \%, 5 \%$ and $5 \%$ (two-tailed test).

\section{Conclusion}

Based on the 2006-2012 national tax survey data as the foundation, with VAT as the breakthrough point, through the description statistics and double difference (DID) model, the empirical test the VAT tax burden to the enterprise value-added tax reform in our country, fixed assets investment and management benefit of comprehensive effect. Analysis results show that in 2009 after the implementation of value-added tax policy reform, no matter from when or after the longer term, enterprise value-added tax transition regions has a more significant downward trend, lightens the burden of taxpayers; From an investment perspective, tax of enterprises because of the tax reform should be transition region, the increase of cash flow, and so did the fixed asset investment increased significantly, the enterprise investment to further strengthen; Look from the Angle of return on assets, transition region enterprise economic benefits have increased significantly, illustrate the VAT reform caused by the increase in investment spending does not damage the enterprise management efficiency, but to a certain extent, improve the enterprise's business performance. 


\section{Literature References}

[ 1 ] Auerbach A. J. Tax Reform and Adjustment Cost: the Impact on Investment and Market Value [ R ] . NBER Working Paper, 1986: 2103.

[ 2 ] Card D. , Krueger A. B. Minimum Wages and Employment: a Case Study of the Fast-food Industry in New Jersey and Pennsylvania[ J ] . American Economic Review, 1994, 84( 4) : $772-793$.

[ 3 ] Cutler D. M. Tax Reform and the Stock Market: an Asset Price Approach [ J . American Economic Review, 1988,78( 5) : 1107-1117.

[ 4 ] Jensen M. Agency Costs of Free Cash Flow, Corporate Finance, and Takeovers

[ J ] . American Economic Review, 1986,76( 2) : 323-32.

[ 5 ] Jensen M. The Modern Industrial Revolution, Exit, and The Failure of Internal Control Systems [ J ] . Journal of Finance, 1993, 48( 3) : 831-880. 